ISSN-2379-7959

Volume 5, Issue 1, 6 Pages

\title{
Extraction and Immobilization of Proteolytic Enzymes from Local Yemeni Bean Seeds (Dolichos Lablab L.)
}

\author{
Maher Ali Al.Maqtari ${ }^{1 *}$, Khalid Mohammed Naji ${ }^{2}$, Lena Kassem Ali ${ }^{3}$ \\ ${ }^{1,2}$ Chemistry Department, faculty of Science, Sana'a University, Yemen. \\ ${ }^{3}$ Faculty of Medicine, Taiz University, Yemen. \\ al.maqtarimaher@yahoo.com
}

\begin{abstract}
The aim of this study was to prepare immobilized protease with high hydrolytic activity for biotechnological applications. Yemeni Bean Seeds (Dolichos Lablab L.) were used for extraction of acid protease using tris-buffer, pH 4.5 as enzyme solvent. Free acidic protease was immobilized on entrapment in calcium alginate gel (in situ activated) by covalent binding method. Their activity and immobilization efficiency for hemoglobin hydrolysis was investigated. Temperature and $\mathrm{pH}$ maxima of the immobilized protease showed no changes before and after immobilization. The immobilized protease exhibited good thermal stability and re-usability.
\end{abstract}

Keywords: Acid protease, Yemeni Bean Seeds, Immobilization, Optimization.

\section{INTRODUCTION}

Enzymes are very efficient catalysts which serve to accelerate the biochemical reactions of living cells and catalyze a variety of chemical reactions. They speed up biochemical reactions by lowering the energy of activation without themselves appearing in the reaction products[1]. Enzymes may be immobilized by a variety of methods, as shown in figure 1, which may be broadly classified as Physical methods; where weak interactions between enzyme and support material exist and to Chemical methods; where covalent bonds are formed between the enzyme and the supporting material [2].

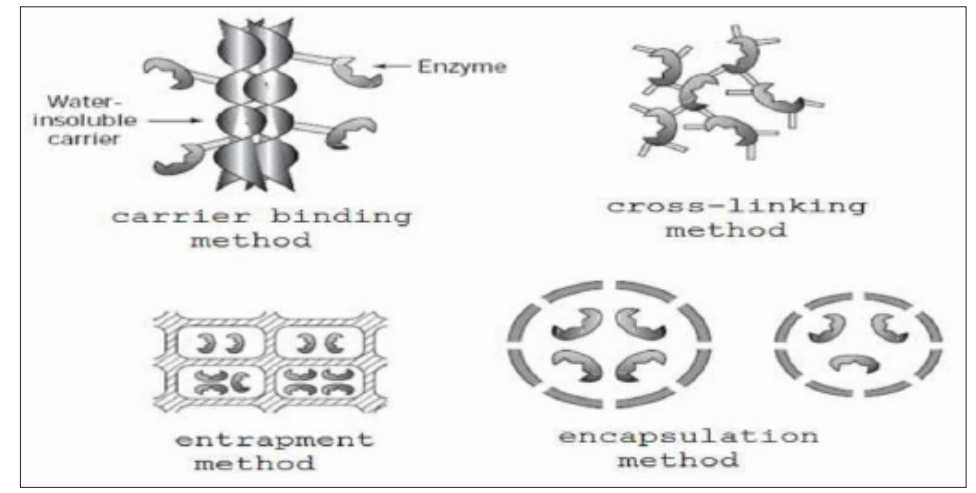

Fig1. Enzyme Immobilization Methods

Enzyme immobilization has attracted a wide range of interest from fundamental academic research to many different industrial applications. Immobilized biocatalysts are freely used in the production of medicines, chemicals, food, beverages and wastewater treatments [3]. The basic idea behind enzyme immobilization is to restrict the freedom of the enzyme by fixing it to solid supports or within a semi-permeable support material, which prevents the enzyme from leaving while allowing substrates, products, and co-factors to pass through[4]. 
Immobilization on solid carriers is perhaps the most used strategy to improve the operational stability of biocatalysts [5,6]. Seeds of (Dolichos lablab L.) is a species of bean in the family Fabaceae. It is native to Africa and it is cultivated throughout the tropics for food. It is the only species in the monotypic genus Lablab[7]. Yemeni bean (Dolichos lablab) both in tender green and mature dry stages is consumed after cooking in Yemen, India and parts of South America.

The efficiency of the free enzyme and the immobilized protease will be determined by estimating some physicochemical properties such as reuse.

\section{Materials and Methods}

\section{Plant Material and Chemicals}

The Dolichos lablab L. seeds were obtain from local market in republic of Yemen. All the chemicals were of analytical or electrophoresis grade. All chemicals were purchase from Sigma Aldrich, Himedia (Indian company). Deionized water was use throughout the experiments.

\section{Enzyme Extraction and Purification}

The seeds approximately 24 grams were wash separately with $1 \% \mathrm{HgCl}_{2}$ and wash allot distilled water and then soaked in distilled water at room temperature overnight germination. After that, the seeds were ground by electric homogenizer. Then the homogenates were finely powder in magnetic stirrer mixed with $10 \mathrm{mM}$ Tris$\mathrm{HCl}$ buffer at $\mathrm{pH} 7.2$ for $3 \mathrm{~h}$. The extracted mixtures were centrifuge at $4000 \mathrm{rpm}$ for $30 \mathrm{~min}$ below $4^{\circ} \mathrm{C}$ and collected supernatant. Proteins were precipitate from crude extract using $80 \%$ ammonium sulfate saturation. Precipitates were centrifuge at $4000 \mathrm{rpm}$ for $20 \mathrm{~min}$ below $4^{\circ} \mathrm{C}$. The pellets were re-suspended in $10 \mathrm{mM}$ Tris$\mathrm{HCl}$ buffer $\mathrm{pH} 7.2$ [8] and dialyze extensively against the same buffer. The dialyzed ammonium sulfate fraction was loaded on to a DEAE-cellulose column $(1.5 \mathrm{~cm} \mathrm{X} 15 \mathrm{~cm})$ pre-equilibrated with $10 \mathrm{mM}$ Tris-HCl buffer $\mathrm{pH}$ 7.2 and eluted with same buffer with a salt concentration gradient of $0-1 \mathrm{M} \mathrm{NaCl}$. Absorbance of the fractions at $280 \mathrm{~nm}$ was measured in spectrophotometer. The active and catalytically enriched fractions were pool. Tee fraction collected was placed on the top of sephadex G-70 column then was eluted with $10 \mathrm{mM}$ Tris-HCl buffer $\mathrm{pH} 7.2$, which was monitored through spectrophotometer at $280 \mathrm{~nm}$.

\section{Protein Measurement}

Protein concentration was determined by the method of [9] using bovine serum albumin (BSA) as standard protein. ${ }^{(11)}$ The amount of the soluble protein was calculated from the standard curve as my of protein per $\mathrm{ml}$ of test sample.

\section{Enzyme Assay}

Proteolytic activity was assayed by following the modified method of [10] for soluble enzyme using casein $(0.65 \%)$ as substrate, $10 \%$ trichloroacetic aid (TCA) for stop reaction, after separate supernatant by centrifuge mix with $500 \mathrm{mM} \mathrm{Na}_{2} \mathrm{CO}_{3}$ and double times diluted folinciocatored reagent (FCR). After vigorous mixing, the color was allow developing for $30 \mathrm{~min}$ and was monitored using spectrophotometer at $732 \mathrm{~nm}$.

One unit $(U)$ protease was define as the amount of enzyme that hydrolyzed casein to releases $1 \mu$ mol of tyrosine per minutes at $37^{\circ} \mathrm{C}$. The specific activity was express in the units of enzyme activity per milligram of protein $(\mathrm{u} / \mathrm{mg})$. The enzyme activity computation in $(\mathrm{u} / \mathrm{ml})$ were made using the following equation.

\section{Electrophoresis}

Purity of enzyme preparation was assessed through with sodium dodecyl sulfate-polyacrylamide gel electrophoresis (SDS-PAGE) system (Adjustable vertical gel system) using slab gel $(0.5 \mathrm{~mm}$ thick, 10\% polyacrylamide) by following the method [11]. The protein in the gel were stained with Coomassie Brilliant blue R-250. 


\section{Determination of Molecular Weight by SDS-PAGE}

Sodium dodecyl sulphate-Polyacrylamide gel electrophoresis of purified protease was carried out according method of [12.].

\section{Immobilization of Protease}

Calcium alginate [13] Sodium alginate suspension (3\%) was prepared by suspending $0.9 \mathrm{~g}$ sodium alginate in $30 \mathrm{ml}$ boiling water and autoclaved at $121^{\circ} \mathrm{C}$ for $15 \mathrm{~min}$. The suspension was cooled to room temperature and $47 \mu \mathrm{l}$ cell suspensions (equivalent to $0.03 \mathrm{~g}$ dry cell weight) was added and mixed for $10 \mathrm{~min}$ by stirring with a glass rod. This was taken in a sterile syringe and added drop wise into chilled $0.2 \mathrm{M} \mathrm{CaCl}$ solution from $5 \mathrm{~cm}$ height with constant stirring. The beads obtained were kept for curing at $4^{\circ} \mathrm{C}$ for $1 \mathrm{~h}$ in refrigerator. The cured beads so formed were washed with sterile distilled water and preserved in $0.9 \% \mathrm{NaCl}$ solution at $4^{\circ} \mathrm{C}$. All the operations were carried out aseptically under a laminar flow hood.

\section{Characteristics of Immobilized Enzyme}

\section{Effect of pH to Immobilized Enzyme Activity}

Immobilized enzyme reacts to Casein in different $\mathrm{pH}$ values within 10 minutes, at $45^{\circ} \mathrm{C}$. After reaction, we determine the immobilized enzyme activity in these $\mathrm{pH}$ values $(3.0,3.5,4.0,4.5,5.0,5.5,6.0,6.5,7.0)$

\section{Effect of Temperature on Immobilized Protease Activity}

Immobilized enzyme reacts to Case in different temperature values within 10 minutes, at determined $\mathrm{pH}$. After reaction, we determine immobilized enzyme activity in these temperature values $(30,40,50,55,60,70,80$, $\left.90^{\circ} \mathrm{C}\right)$.

\section{RESULTS AND DisCUSSION}

In the present study, we have purified and characterized protolytic enzyme from seeds of Dolichos lablab L.by ammonium sulfate precipitation, DEAE-cellulose and sephadex G-70 column.

Our data showed that the $0-80 \%$ ammonium sulfate saturation fraction correlated with highest protolytic enzyme and specific activities compared with the crude protolytic enzyme and other fractions. ${ }^{(16)}$ The purification procedures of the protolytic enzyme secreted by tested seeds are summarized in (table 1). The results showed that the protolytic enzyme was purified 1.074 folds with a specific activity of $40.82 \mathrm{u}_{\mathrm{mg}}{ }^{-1}$ enzyme after ammonium sulfate fractionation. The protolytic enzyme was then purified using DEAE-cellulose column and resulted in 1.422 folds purification with a specific activity of $215.4 \mathrm{u}_{\mathrm{mg}} \mathrm{m}^{-1}$. The final purification step presented 7 fold enzyme purification with a specific activity of 266.34 u.mg ${ }^{-1}$. The yield of the enzyme after purification was found to be $54.06 \%$.

Table1. Purification of protolytic enzyme from $12 \mathrm{~g}$ seeds.

\begin{tabular}{|c|c|c|c|c|c|c|c|}
\hline Step & $\begin{array}{c}\text { Volume } \\
(\mathrm{ml})\end{array}$ & $\begin{array}{l}\text { Total protein } \\
\text { (mg) }\end{array}$ & $\begin{array}{c}\text { Total } \\
\text { activity (u) }\end{array}$ & $\begin{array}{c}\text { Enzyme } \\
\text { activity } \\
(\mathrm{u} / \mathrm{ml})\end{array}$ & $\begin{array}{l}\text { Specific } \\
\text { activity } \\
\text { (u/mg) }\end{array}$ & $\begin{array}{c}\text { Purification } \\
\text { fold }\end{array}$ & $\begin{array}{l}\text { Yield } \\
(\%)\end{array}$ \\
\hline Crude & 102 & 26 & 1010 & 9.9 & 38 & - & 100 \\
\hline$\left(\mathrm{NH}_{4}\right) \mathrm{SO}_{4} \mathrm{0-80} \%$ & 80 & 23.52 & 960 & 12 & 40.82 & 1.074 & 95.05 \\
\hline DEAE-chromatography & 90 & 3.25 & 700 & 7.8 & 215.4 & 1.422 & 69.31 \\
\hline Sephadex G-70 & 30 & 2.05 & 546 & 18.2 & 266.34 & 7 & 54.06 \\
\hline
\end{tabular}

SDS-PAGE analysis of the proteins at each step of purification shows that revealed a monomer band with a molecular weight of $50 \mathrm{KDa}$ (figure 2). 


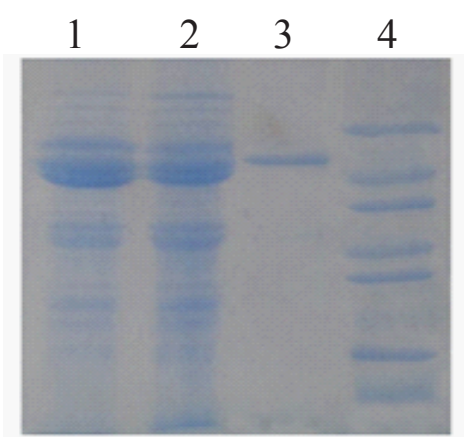

(A)

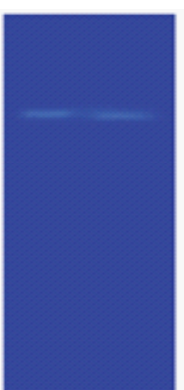

(B)

Fig2. Electrophoretic analysis of protease.(A) lane 1 is crude lane 2 is crude after ammonium sulfate purification lane 3 enzyme purified by chromatography lane 4 standard protein. (B) protein activity on zymograme.

\section{Immobilization of ACID Protease}

Purified protease enzyme after immobilization show in figure 3.

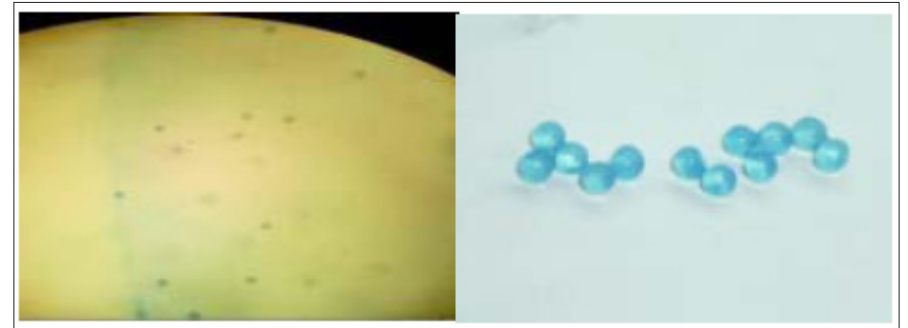

Fig3. Enzyme inside alginate bad \& Beasds dyed bradford

\section{Characterization OF IMMOBILIZED EnZYME}

\section{Effect of pH to Immobilized Enzyme Activity}

In this experiment, immobilized enzyme with Casein solution in $\mathrm{pH}$ range (4-7), within 10 minutes, $45^{\circ} \mathrm{C}$. We also perform the control test using free enzyme. Results of immobilized enzyme activity on Casein at different $\mathrm{pH}$ values are shown in figure 4 .

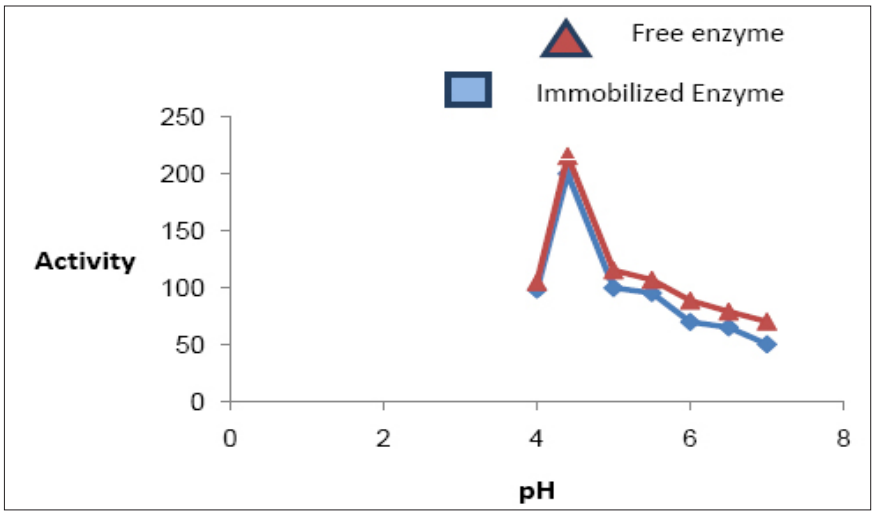

Fig4. Immobilized and free enzyme activity at different $\mathrm{pH}$ values.

\section{Effect of Temperature on Immobilized Enzyme Activity}

In this experiment, immobilized enzyme with Casein in the temperature rang ( 10 to $\left.90^{\circ} \mathrm{C}\right)$, in 10 minutes, at $\mathrm{pH}$ 4.5. We also conduct the control tests with free enzyme. Results of immobilized enzyme activity on Casein at different temperature values are shown in figure 5. 


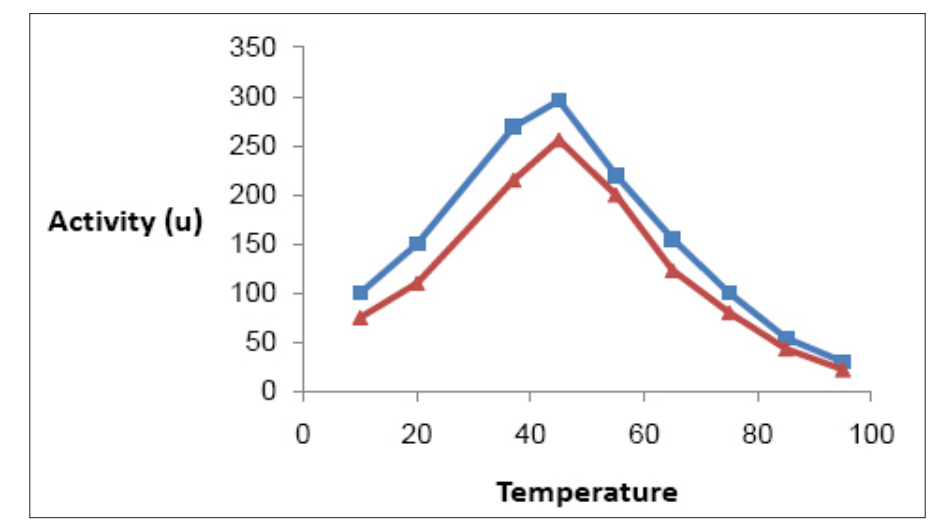

Fig5. Immobilized enzyme activity at different temperature values.

Enzyme immobilization on solid supports represents an efficient approach to improve enzyme stability as well as offering unique merits over the soluble biocatalyst such as operational stability, reusability of the enzyme, bioprocess control, and simplifying product separation $[14,15]$.

Among different immobilization techniques entrapment in calcium alginate gel offers many advantages due to its simplicity and nontoxic character[16].

The catalytic behavior of the immobilized enzyme was examined on hemoglobin in terms of enzyme activity, stability and reuse in an aqueous medium at variable $\mathrm{pH}$ and temperatures.

Temperature and pH maxima of the immobilized enzyme showed no changes before and after immobilization this result agreed with study of [17]. The domination of processed food in the modern human Diet results in a lack of active exogenous enzymes and as a consequence-a rapid depletion of their metabolic reserves.

Since enzymes found in food are an important part of maintaining a healthy diet. The food rich in active enzymes, especially proteases, is applied as an important therapeutic and anti-aging diet component[18].

\section{CONCLUSION}

The immobilized enzymes on calcium alginate gel are prepared for purpose of repeated use and the possibilities of continuous reaction system. One of the most important properties is the stability of proteins when they are used in some medical and industrial applications. The immobilization of the enzymes improves this property as well as many other properties. In this study, protease was purified and immobilized on calcium alginate gel. protease was used in this study for its biological and industrial applications It is used in paper textile, pharmaceutical applications, food, and detergent industries. The reuse efficiency of the free and immobilized enzymes showed the immobilized enzymes showed same in the relative activity.

\section{REFERENCES}

1. Emel, E., Sibel, S. and Ural, A., (2006): Polyacrylamide-gelatine carrier system used for invertase immobilization. Food Chemistry, 97: 591-597.

2. Arıca, Y. and Bayramoglu, G., (2004): Reversible immobilization of tyrosinase onto polyethyleneiminegrafted and $\mathrm{Cu}$ (II) chelated poly (HEMAco-GMA) reactive membranes, Journal of Molecular Catalysis B: Enzymatic, 27: 255-265.

3. Saleem, M., Rashid, M., Jabbar, A., Perveen, R., Khalid, A. and Rajoka, M., (2005): Kinetic and thermodynamic properties of an immobilized endoglucanase from Arachniotus citrinus. Process Biochemistry, 40: 849855. 
4. Abdel-Fattah, A., Osman, M. and Abdel-Naby, M., (1997): Production and immobilization of cellobiase from Aspergillus niger A20, Chemical. Engineering., 68:189-96.

5. Garcia-Galan C, Berenguer-Murcia A, Fernandez-Lafuente R, Rodrigues RC (2011) Potential of different enzyme immobilization strategies to improve enzyme performance. Adv Synth Catal 353: 2885-2904.

6. Aissaoui N, Landoulsi J, Bergaoui L, Boujday S, Lambert JF (2013) Catalytic activity and thermostability of enzymes immobilized on silanized surface: influence of the crosslinking agent. Enzyme Microb Technol 52: 336-343.

7. Hedstrom, L. (2002):Serine protease mechanism and specificity. Chem Rev 102(12): 4501-24.

8. Akhtaruzzaman, M. N.H.M,Rubel, R. Jamal, A. Rahman and Rahman, T.(2012): Isolation and characterization protease enzyme from leguminous seeds. Agricultural Science 2(8): 434-440.

9. Lowry, O.H., Rosebrough, N. J., Farr, A. F. andRandall, R. J. (1951): Protein measurement with Folin Phenol Reagent. Biological chemistry 193: 265-275.

10. Anson, M.L. (1938): The Estimation of pepsin, Tripsin, Papain and cathepsinwith Hemoglobin. General Physiology 22: 79-89.

11. Laemmli, UK (1970): Cleavage of structural proteins during the assembly of the head of bacteriophage T4. Nature 227(5259): 680-685.

12. Smith, B.J. (1984): SDS Polyacrylamide gel electrophoresis of proteins. Method in molecular Biology 41-56.

13. Johnsen A and FlinkJM. Influence ofalginate properties and gel reinforcement on fermentation characteristics of immobilized yeast cells. Enz. Microb. Technol. 1986, 8:737-748.

14. Mateo, C.; Palomo, J.M.; Fernandez-Lorente, G.; Guisan, J.M.; Fernandez-Lafuente, R. Improvement of enzyme activity, stability and selectivity via immobilization techniques. Enzyme Microbiology Technology. 40, 2007, 1451-1463.

15. Kumar, A.G.; Swarnalatha, S.; Kamatchia, P.; Sekaran, G. Immobilization of high catalytic acid protease on functionalized mesoporous activated carbon particles. Biochemistry Eng. J. 43, 2009, 185-190.

16. Geethanjali, S. and Anitha, S. Optimization and immobilization of purified Labeo rohita visceral protease by entrapment method. Enzyme research, 2013, 874050.

17. Abida A., Shah A., Aliya R., Samina I. and Abid A.. Calcium Alginate: A Support Material for Immobilization of Proteases from Newly Isolated Strain of Bacillus subtilis KIBGE-HAS. World Applied Sciences Journal 7 (10), 2009, 1281-1286.

18. Rafat, R., Przemystaw, T., Matgorzata, D. and Klaudia, K. The evidence in sprouted seeds and their application for animal protein digestion. Chemical papers, 72, 2018, 1213-1221.

Citation: Maher Ali Al.Maqtari, Khalid Mohammed Naji, Lena Kassem Ali, "Extraction and Immobilization of Proteolytic Enzymes from Local Yemeni Bean Seeds (Dolichos Lablab L.)". American Research Journal of Biosciences; vol 5, no 1; pp: 1-6.

Copyright (c) 2019 Maher Ali Al.Maqtari, Khalid Mohammed Naji, Lena Kassem Ali, This is an open access article distributed under the Creative Commons Attribution License, which permits unrestricted use, distribution, and reproduction in any medium, provided the original work is properly cited. 